Trivent Publishing

(C) The Authors, 2016

Available online at http://trivent-publishing.eu/

Series: Engineering and Industry

Volume: Watershed and River Basin Management

\title{
Water Quality Study of the Itaparica Reservoir, São Francisco River, Brazil
}

\author{
Gustavo Lira de Melo, ${ }^{1}$ Maria do Carmo Sobral, ${ }^{1}$ Günter Gunkel ${ }^{2}$ \\ ${ }^{1}$ Department of Civil Engineering, Federal University of Pernambuco - UFPE. Av. Acadêmico Hélio Ramos, s/n \\ 50670-530 Recife PE, Brazil, gustmelo@gmail.com; msobral@ufpe.br \\ ${ }^{2}$ Department of Water Quality Control, Technical University of Berlin - TU Berlin. Strasse des 17 Juni, 135, \\ Sekr KF-4, 10623 Berlin, Germany, guenter.gunkel@tu-berlin.de
}

\begin{abstract}
The reservoir of Itaparica is located in the physiographic area called São Francisco sub-medium region, Brazil. It was constructed in 1987 with the priority purpose of energy generation. However, it presents multiple uses as public and industrial supplying, irrigation, aquaculture, cattle, navigation, and tourism with great part of its irrigated perimeter using fertilizes, and irregular occupations on its surrounds, as well as several kinds of effluents coming directly into the reservoir without treatment. The purpose of this work was to evaluate the water quality of the Itaparica reservoir using the monitoring and bibliographical sources, as a support to management improvements and consequently, improvements on the water resources in the semi-arid region of Pernambuco. Water quality degradation was observed along the years, and the reservoir is in eutrophization process, with concentrations of total phosphorus, and phytoplankton out of the standards established by Resolution Conama $n^{\circ} 357 / 2005$. Implementation of control action becomes important like the reduction of sewage effluents inputs and the protection of the permanent preservation areas. An increase on the spatial and temporal frequency sampling data of the water quality becomes necessary, and it should set up new sampling points for a better evaluation of the eutrophization in the reservoir.
\end{abstract}

\section{Keywords}

Itaparica reservoir; water quality; monitoring; semi-arid

This is an Open Access article distributed in accordance with the Creative Commons Attribution Non Commercial (CC-BYNC-ND 4.0) license, which permits others to copy or share the article, provided original work is properly cited and that this is not done for commercial purposes. Users may not remix, transform, or build upon the material and may not distribute the modified material (http://creativecommons.org/licenses/by-nc/4.0/) 


\section{Introduction}

Most of the water used for public supply in the state of Pernambuco, Brazil, comes from surface reservoirs. Most of the rivers, for crossing urban areas, find themselves in high process of degradation, concentrating large amounts of pollutants that are carried to the reservoirs, compromising the quality of water for public supply.

Thus, surges the need to introduce new ways for the management of water resources, which focus on specific alternative to each region, through a shared management with various institutions, with the private sector and with society, in order to find solutions to protect these resources.

This environmental management and protection of aquatic ecosystems are guaranteed internationally, as one of the foundations for a sustainable and of good quality supply, as required and made, among others, by the Water Directive of the European Union (EU, 2000) or the Health Ecosystem Concept of the United States (EPA, 1998).

This research aimed to evaluate the water quality in the reservoir of Itaparica, in order to propose improvements to the management of the reservoir and, consequently, of water resources in the semiarid of Pernambuco.

\section{Methods}

The collection of primary data took place through systematic observations (direct and indirect) and interviews with local people who have to be relocated because of the reservoir's construction, Chesf (Hidro-Electrical Company of São Francisco) employees (and outsourced) involved with the resettlement projects, community leaders, agricultural technicians and agronomists, accompanied by photographic record. The collection of secondary data was based on the following researches: literature, documentary, cartographic and the lifting of the relevant literature.

There were used reports from the Program of Limnologic Monitoring and Water Quality Assessment of the Itaparica Reservoir 2004 and 2005, created by Chesf and conducted by the Planning and Transport and Consultancy (PETCON) with the aim of using tools to obtain the Operation license (LO) with the national licensor, the Brazilian Institute of Environment (IBAMA).

\section{The Itaparica Reservoir}

The reservoir of Itaparica (Figure 1) is situated along the São Francisco River in the physiographic region called Submedium of São Francisco. It has a storage capacity of the order of 11 billion $\mathrm{m}^{3}$ of water, with maximum depth of $101 \mathrm{~m}$, average of $21 \mathrm{~m}$ and area of $834.0 \mathrm{~km}^{2}$.

Since the reservoir of Itaparica started operating in 1988, with the flood of $805 \mathrm{~km}^{2}$, a series of environmental problems has been observed as a consequence of uncontrolled use of the lake margin for agricultural activities and urban occupations. The creation and expansion of urban areas close to the lake`s margins have contributed to the release, into this, untreated domestic sewage (SOBRAL, et. al, 2006). 


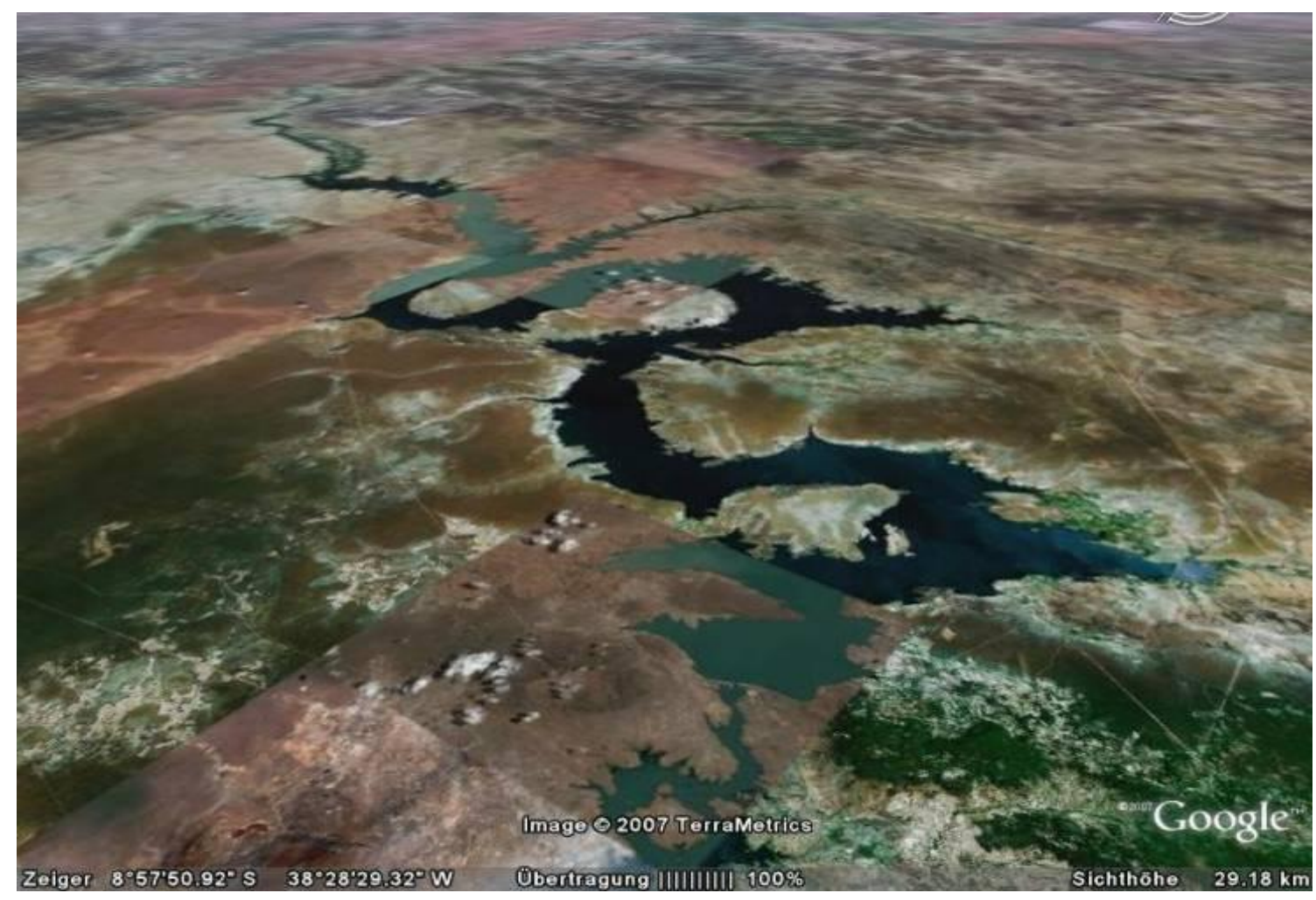

Fig. 1. Reservoir of Itaparica, Google Earth $₫ 2007$

\section{Results and discussion}

During the Chesf monitoring Program, collections were held in January, April, July and October 2004 and in January, April and July 2005, and 29 collection stations were examined.

The reservoir presented good level of oxygen, with concentrations ranging from 4.6 to $11.7 \mathrm{mg} / \mathrm{L}$ on the surface. The electrical conductivity and turbidity parameters showed the same behavior. In the months of July and October, periods of drought, the lowest concentrations were found. In the months of January and April, the rainy season, the highest concentrations were observed, showing a seasonal variability, this fact was also observed by Braga et al. (1999), when it was found that the main parameters showed variations related to the two periods of the year (dry and wet).

Among the nitrogen forms, nitrite, nitrate and ammonia had, in general, small concentrations. The total nitrogen showed the highest concentrations among the nitrogen forms, ranging from 124,49 to $979,7 \mu \mathrm{g} / \mathrm{L}$.

The concentrations of orthophosphate were, in general, low, especially in the dry season. The concentrations of total phosphorus were, in general, below the limits set by CONAMA resolution $\mathrm{n}^{\circ}$ 357 / 2005 for fresh waters of the Class 2 (Figure 2). However, it also showed high concentrations, especially in the month of April 2004.

Regarding the phytoplankton, 172 taxons of planktonic algae were identified. Regarding the cyanobacteria, densities above the limits set by CONAMA resolution No 357 / 2005 for class 2 (50,000 cells/ mL) and the Order 518 / 2004 of the Ministry of Health, were found, especially in the month of July/04. 


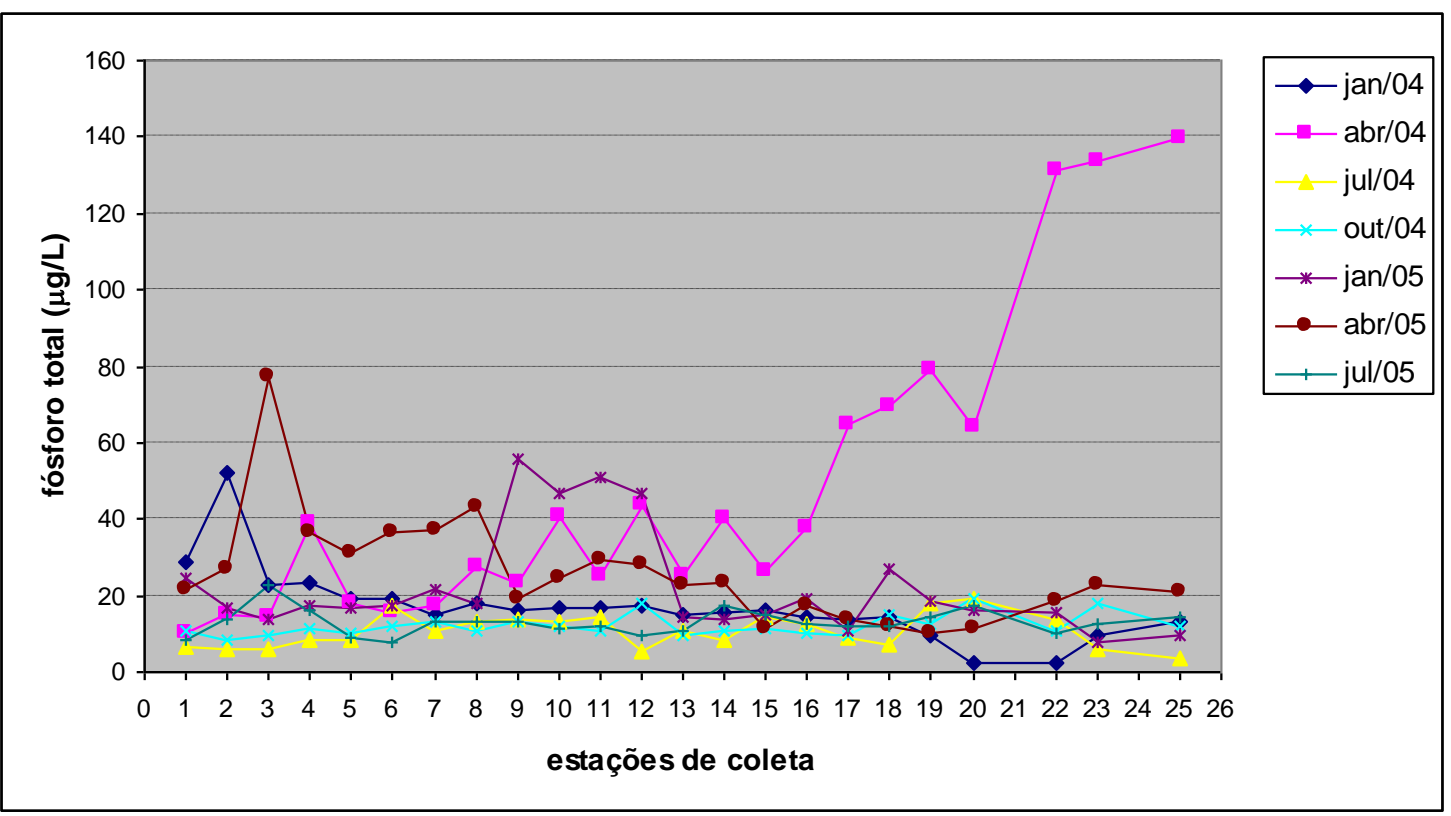

Fig. 2. Variation of the total phosphorus concentration in the surface of Itaparica reservoir during 2004 and 2005

\section{Conclusions}

The reservoir presented concentrations of orthophosphate and total phosphorus above the permitted by the CONAMA resolution No 357 / 2005, demonstrating that the reservoir is starting the process of eutrophication; the launching of effluents of cities located around the reservoir, the input of organic matter and sediments from rivers and the use of chemicals in agriculture are the main sources of water contamination in the reservoir of Itaparica, and the water from the catchment points for public supply is compromised because by the presence of cyanobcterias blooms at some periods of the year.

\section{Aknowledgments}

The authors acknowledge the support of the Coordination of Improvement of Personnel of Higher Education - CAPES and the DAAD through the program PROBRAL n. 238/06 between TU Berlin and UFPE, as well as the support of the Chesf.

\section{References}

BRAGA, J. D. B.; BRAGA, E. G. P.; PEREIRA, S. M. B.; LEÇA, E. E.; TEIXEIRA, M. G. (1999) Programa de controle de macrófitas aquáticas no complexo hidrelétrico de Paulo Afonso e na UHE Itaparica. In: Seminário nacional de produção e transmissão de energia elétrica - SNPTEE. 15, 1999, Paraná, Anais... Paraná.

EUROPEAN UNION (2000). Directiva 2000/60/CE do Parlamento Europeu do Conselho de 2310-2000. L327/1, EU.

Environmental Protection Agency - EPA (1998). Office of Water.Lake and Reservoirs Bioassessment and Biocriteria. Technical Guidance Document. EPA 841-B-98-007. U.S. Washington, D.C. 